\title{
Language Diversity and Language Policy in Education in Nigeria - A Critical Review
}

\author{
Blessing Anukaenyi \\ Department of Arts and Social Science Education Faculty of Education, Godfrey Okoye \\ University. Thinkers Corner, Emene, Enugu State, Nigeria.
}

\begin{abstract}
It is estimated that over 60 percent of Nigerians are under the age of 24 . This number can be either a burden or blessing to the nation. This means there is need to make every citizen count. There is need for high value or productive citizens. In other words, there is need for high value knowledge economy that comes with quality education. It is in recognition of this critical role of education that the 1979 Constitution that brought presidential systems of government gave birth to the 1981revised edition of the national policy on education. The five main objectives of the philosophy of Nigerian education, as stated in the policy document 1981- revised edition are: a free and democratic society; a just and egalitarian society; a united, strong and self-reliant nation; a great and dynamic economy; and a land of bright and full opportunities for all citizens. The above objectives seem to have symbiotic relationship in the light of contemporary socio-economic and political trends in Nigeria. However, the policy objectives of education in Nigeria are couched in English language been the nation's lingua Franca and as such Language of Education at all levels. It should be realised that a great number of Nigerians do not speak the language in which all the education policy in Nigeria is written. Nigeria has over 250 linguistic ethnic groups. This means that even if the will to be democratic, egalitarian, a united, strong and self-reliant nation; a great and dynamic economy; and a land of bright and full opportunities for all citizens were there, and even if most Nigerians were otherwise literate and able to access the policy materials, or if someone read it to them, half of the country's population would not understand the language in which the goals are stated in the first place. To put it in numbers, approximately ninety million Nigerians $(53 \%$ of the population) do not and also cannot speak English. They cannot therefore, understand the National Policy of Education or hardly any policy decision making at national level for that matter. There are therefore, convincing reasons to believe that issues related to language diversity and language policy in education have been one of the major factors responsible for poor education content and poor student academic performance in the Nigerian educational system. Using an exploratory
\end{abstract}


design with anecdotal evidence and envisaging a historical survey of education policy in Nigeria, the proposed study (or paper) seeks to establish the link between language diversity and language policy in education and poor performance of education sector in Nigeria.

Keyword: Education policy, national policy, language diversity, philosophy of education.

\section{INTRODUCTION}

In Nigeria, language policy on education dates back to the colonial era when in 1927 the British Advisory Committee on native education in tropical Africa recommended that indigenous languages should serve as medium of instruction in the lower years of primary education (Musa, 2010). Language policy on education has remained a contemporary concern in the highly multiethnic and multilingual Nigeria with about 500 indigenous languages spoken within its borders (Blench, 2002). English language was the medium of instruction before the National Policy on Education advocated the use of indigenous languages in teaching at basic level of education. Language plays different roles such as officialdom, legislature, mass media, politics, official business, education etc. in a particular setting.

The scope of this study is the role of language in education. Language here can either be language learnt and taught in the educational system or the language used for educating at various levels and sectors of a national system (Obanya, 2004). This review deals with the use of languages in education both as languages learnt/taught and used for instructional reasons. The Encyclopedia defines multilingualism as the use of several languages either by an individual speaker or by a community of speakers. Multilingual education in this context is therefore, the use of several languages in educational system.

Terry (1977) sees policy as "an overall guide that gives the general limits and direction in which administrative action will take place." This implies that policy only defines the area in which decisions can be made but cannot give the decision, instead ensures consistency of an action since an administration is governed by approved principles. The concentration here is on Educational policy which gives the direction for educational activities. Despite the fact that the government through the National Policy on Education can be said to favour the use of two or more languages in the educational system, implementation of the multilingual provisions has been a serious issue. In an attempt to find out the different factors responsible for the poor implementation of these provisions, scholars have identified possible challenges which include:

- Multi-lingual challenge;

- $\quad$ Negative attitudes of students;

- Lack of curriculum materials

- $\quad$ Ambiguities in the policy; 
- Parental factors;

- Teacher quality.

Having outlined the possible contemporary issues facing the implementation of complete use of indigenous languages as medium of instruction in schools, a research was carried out to study the current state of educational policy in Nigeria, highlighting specific issues on the challenges of multilingual education and future of English language. This study also tries to examine the effectiveness of the English language in the advancement of the nation's ' educational sector, with the hypothesis that provisions of multilingual education contained in the National Policy on Education (NPE) are not properly implemented. In achieving the set objectives of this study, the following questions were raised:

1. Are educational goals in line with educational policies in Nigeria?

2. Do schools implement the multilingual provisions of the NPE?

3. What is the students' perception of multilingual education?

4. What is the status of multilingual education provisions - the NPE in Nigeria?

5. What skills have teachers acquired in the English language

6. What is the future of English language $m$ the Nigerian educational sector?

\section{Multilingual Policy on Language Education in Nigeria}

The language of instruction in multilingual Nigeria has always been a matter of concern to educators and educational planners. The African situation is aptly captured by Ouadraogo (2000) when he asserts that, "education and language issues are very complex in Africa because of the multi-ethnic and multi-lingual situations". Due to this linguistic plurality, the government appreciated the importance of language as a means of promoting social interaction and national cohesion as well as preserving culture. Thus, there was the need for language policy, planning and development as well as implementation. In 1977, an official document titled National Policy on Education was promulgated which was revised in 1981, 1998 and 2004. This document assigned different functions to the languages in the nation's education at various levels. The policy stated that every child shall learn in the language of the immediate environment in the first three years while English language shall be taught as a school subject. However, in the interest of national unity among the various ethnic groups in Nigeria, every child shall require to learn one of the three national languages (Hausa, Igbo, Yoruba).The provision of the NPE (2004), Section 4, Paragraph 19 (e) and (f) cited below confirms that the multilingual education is in existence:

The medium of instruction in the primary school shall be the language of the environment for the first three years. During this period, English shall be taught as $j$ subject, from the fourth year, 
English shall progressively be used as a medium of instruction and the language of immediate environment and French shall be taught as subjects.

The policy made it explicit that from the fourth year of basic education, the medium of instruction shall be English language while the language of the immediate environment and French shall be taught as subjects. At secondary level, English shall be the languages of instruction while the language of the immediate environment, one of the three major Nigerian languages (Hausa. Igbo, Yoruba) other than that of the immediate environment and French shall he taught as school subjects.

Levels of Education in Nigeria are:

1. Early childhood (pre-primary);

2. Basic education (9 years) - comprising Primary and Junior secondary

3. Education;

4. Senior Secondary Education (3 years);

5. Tertiary Education.

\section{Role of English Language in Nigeria}

Decades after decolonization English language being the language of the colonial masters still enjoys primacy through its significant role in the integration of the Nigerian nation that is made up of made up of three different regions of North, East and West. Hausa is the predominant language of the northerners, Igbo of the Easterners and Yoruba of the westerners. Each region has many other minority groups within it. Nigeria's multiplicity of languages is so obvious that languages of people living within a 20 kilometres radius are particularly different and not understandable to one another (Danladi, 2013). The implication of this linguistic situation has been the lack of a common effective means of communication among the groups and this became the basis for resorting to use the English language as a medium of instruction in educational settings, since the choice of any of the three main native languages as a national language may deteriorate to disintegration. According to Odebunmi (2005), English is institutionally the only means open to individuals from different ethnic and linguistic groups for interaction. This shows the dominance of English in the Nigerian setting. From earliest stage to date, English has been playing dual roles as a contact language between different ethnic groups and a medium of communication at international levels particularly in the area of commerce and diplomacy, though in different usages. Despite all constitutional provisions, English still controls almost all methods of instructions in all levels of education in Nigeria, while Hausa, Igbo and Yoruba are considered as local languages. English is that Language of unity that speakers of other indigenous languages do code-mix with in their speech. Other speakers see Pidgin English as lingua franca in Nigeria. 
Scholars have identified five dominant roles of English and other mother tongues in Nigeria as: official, educational, mass media, religious observance, and interpersonal relations. However, these roles played by English language can be rooted in its colonial history.

\section{Methodology}

In the cause of this study, a total number of one hundred (100) teachers at basic education level (this comprises lower primary and junior secondary school as listed in the National Policy on Education) in Gusau the capital city of Zamfara State, Nigeria, were selected as participants. The schools in Gusau were stratified into the public and private schools, after which four schools were randomly selected; two from each category. Twenty five (25) teachers were selected through a sample random sampling technique from each school. A twenty item questionnaire was developed and administered to the teachers of relevant subjects to find out students' perception of multilingual education, status of multilingual education provisions on the NPE, teachers' skills in the English language and future of English language in Nigeria. The instrument was divided into four parts to cater for four variables. Each part has five (5) questions four (4) of which were in a "yes", "no", and "not sure" scale - the fifth question in each part was open-ended, mainly to allow the respondents to express themselves appropriately. The participants were told to be objective in the process of responding to the questions. The data were analyzed using frequency counts and percentages.

\section{A Summary of Findings}

From the results of the data analysis, this study arrives at the following deductions:

- Students prefer to be taught in English language but they demonstrate more passion for learning when switched to an indigenous language.

- Majority of the teachers have not been putting into practice the multilingual provisions of the National Policy on Education;

- The government has not taken the implementation of the provision very serious;

- Lack of competence teachers to handle school subjects in the indigenous language.

- Non-availability of appropriate textbooks and other relevant teaching materials in indigenous languages;

- Teachers are prone to show off their skills in the English language even when they do not see it as natural as their indigenous languages;

- The future of English language in the Nigerian educational sector is very bright 


\section{Challenges of Multilingual Education Provisions in Nigeria}

\section{The Multilingual Challenge}

In multilingual Nigeria, it is obvious that the estimated 500 different languages are of unequal statuses. This inequality confirms that linguistic hierarchy is a serious concern in the Nigerian linguistic situation. Consequent upon Nigeria's linguistic diversity is the issue of national unity and cultural integration of the people. This nonexistence of linguistic unity among citizens led to the emphasis placed on English language in the educational sector. Gbenedio (1990) discovered that only about 65 standardized orthographies and only three major languages of Hausa, Igbo and Yoruba have documented efforts of teacher education. In the case of this situation, the challenge is the identification, development and adoption of about five hundred (500) languages for the basic education in the country. Any attempt to compress similar languages in a particular region to promote one that would represent the cultural area would meet with opposition and complain about marginalization from the communities, even when majority of languages do not have standard orthographies.

Ogunbiyi (2008) emphasized that in spite of the provisions of the National Policy on Education and the position of the government on the roles assigned to the English language and indigenous languages in education, some schools still downgrade Nigerian languages to the background and promote the teaching of English language, most especially the private schools.

\section{Poor Policy Planning and Implementation}

Although the use of the child's mother tongue as a medium of instruction for the first three years of basic education as stated in the National Policy on Education (NPE, 2004) is ideal, numerous factors have contributed to the low attainment of the educating goals of basic education in Nigeria. Leading among the factors is poor implementation of educational policies. Okeke et al (1985) opined that good planning will ensure effective implementation. Aghenta (1984) observed that, "for education to achieve all ends, it has to be carefully planned. The plan must take into consideration... the needs of the society; the political, socio-cultural, economic, military, scientific, and technological realities of the environment are very important to its survival."

\section{Teacher Quality and Curriculum Materials}

Another key challenge that contributed to the unsuccessful implementation of the multilingual policies on education in Nigeria is capability problem. There is low turnout of competent teachers in the various indigenous languages to handle school subjects, in other words, there are no graduate teachers of indigenous languages in the right quantity and quality. There is non-availability of teaching materials particularly relevant textbooks in the indigenous languages. It is very common in the Nigerian setting to see that there are many school teachers who do not know how to read or write their native languages. Speaking a language (with semantic errors alone is not enough to qualify a teacher to teach that language. Only quality teachers can succeed in proper 
implementation of any curriculum. This is an unfortunate situation but that appears to be the handwriting on the wall.

\section{Conclusion}

It is important to note that there has never been a structured comprehensive language policy in Nigeria. What has been in existence as a language policy that tends to find solution to language concerns in the country is the National policy on Education enshrined in the constitution. It is in this connection that this study reviewed the language policy and planning on education in Nigeria. The prominence of English and its recognition as language of unity in Nigeria is endangering the Nigerian languages. To preserve the minority languages, the present language policy on education needs to be revised, for example French is no longer relevant in the Nigerian education.

\section{Recommendations}

In line with the entire discussions in this review, the following recommendations may offer a working solution to the multilingual policy for Nigeria:

- $\quad$ The Federal government should fully develop more educational resources and orthographies of indigenous languages to meet the demands of multilingual education

- Nigerian scholars in the field of language should intensity efforts in the codification of aspects of indigenous languages and produce reading materials;

- The government should do more in the enforcement of the multilingual provisions in all sectors of education;

- A team of experts should be paying constant visits to schools to ensure total adherence to the provisions of multilingual education;

- A credit pass in any of the Nigerian should be made a prerequisite to gaining admission into any of the Nigerian Universities;

- Language education programmes should be introduced for schools at basic education level;

- $\quad$ Teachers should be encouraged to jointly help students to develop competence in the use of indigenous languages in a school setting

- $\quad$ There should be adequate training of teachers;

- $\quad$ The government should make available sufficient funds for implementing educational policies 


\section{REFERENCES}

Aghenta, J. A. (1984). Towards effective leadership in school management in Nigeria - A System Approach, Occassional papers / Comparative Education Study and Adaptation Centre, University of Lagos ; no. 6 (Sept).

Blench, R. (2002). Research on minority languages of Nigeria in 2001, Published in the FEL Newsletter, 5(1):1-5

Danladi, S. S. (2013). Language Policy: Nigeria and the Role of English Language in the 21st Century, European Scientific Journal, 9(17): 1-21

Gbenedio, J. (1990). Language Education in Primary Schools in Nigeria: Contemporary Issues and New Direction, Literacy Information and Computer Education Journal (LICEJ), 3(3):1-5.

Musa, A. (2010). Language Policy on Education in Nigeria: Challenges of Multilingual Education and Future of English Language, American Research Journal of English and Literature (ARJEL), 2(10): 1-10

National Policy on Education (2004), $4^{\text {th }}$ Edition, Government Press, Abuja

Obanya, P. (2004). The Dilemma of Education in Africa. Nigeria: Heinemann Educational Books

Odebunmi, A. (2005). Tracking ideology in political news, California Linguistic Notes 35(2):56-78.

Ogunbiyi, O. (2008). The Challenges of Language Teaching in the 21st Century, Pakistan Journal of Social Sciences, 5(4): 297-299

Okeke, B.S, Nosiri, C.P, \& Elele, S.O. (1985). Leadership Styles in Educational Management in Nigeria, A handbook on Educational Administration, Owerri: Pek Publishers.

Ouadraogo, M. (2000). Languages and Education in Africa: a comparative and transdisciplinary analysis, Bristol Papers in Education: Comparative and International Studies.

Terry, M. (1977). The Inevitable Growth of Informality, British Journal of Industrial Relations, 15(1):76-90 